Article

\title{
Green Marketing Approaches and Their Impact on Consumer Behavior towards the Environment-A Study from the UAE
}

\author{
Muhammad Salman Shabbir ${ }^{1, *(1)}$, Mohammed Ali Bait Ali Sulaiman ${ }^{2}$, \\ Nabil Hasan Al-Kumaim ${ }^{3}{ }^{\circledR}$, Arshad Mahmood ${ }^{4}$ and Mazhar Abbas ${ }^{5}$ \\ 1 Department of Management, College of Commerce and Business Administration, Dhofar University, \\ Salalah 211, Oman \\ 2 College of Commerce and Business Administration, Dhofar University, Salalah 211, Oman; \\ msulaiman@du.edu.om \\ 3 Faculty of Technology Management and Technopreneurship, Center of Technopreneurship \\ Development (CTeD), Universiti Teknikal Malaysia Melaka (UTeM) Melaka, Malacca 75460, Malaysia; \\ nabil@utem.edu.my \\ 4 School of Management, Universiti Sains Malaysia, Gelugor 11800, Penang, Malaysia; arshad@usm.my \\ 5 Department of Management, College of Business Administration, University of Hail, \\ Ha'il 55211, Saudi Arabia; m.hussain@uoh.edu.sa \\ * Correspondence: mshabbir@du.edu.om
}

Received: 8 September 2020; Accepted: 7 October 2020; Published: 29 October 2020

\begin{abstract}
The purpose of this study was to analyze the main green marketing approaches and their impact on consumer behavior towards the environment in the United Arab Emirates (UAE). We reviewed the current consumption patterns of green products using a questionnaire approach. For this study, 359 consumers that used any type of green product were selected in various shopping malls in the UAE. For the assessment of questionnaire responses, measurement models, such as confirmatory factor analysis (CFA), and structural equation modeling (SEM) approaches were applied. The findings of the study suggest interesting inferences regarding eco-labeling (EL), green packaging and branding (GPB), green products, premium, and pricing (GPPP), and the environmental concerns and beliefs (ECB) of consumers that affect their perceptions of the environment. Factor analysis provided a goodness of fit for the selected items. It was found that key factors of green marketing, such as EL and GPPP, have a significant positive influence on consumer beliefs towards the environment (CBTE). In addition, environmental concerns and beliefs (ECB) also have a significant and positive influence on CBTE in the UAE. The practical significance of this study is that it will help the progress of the integration of green marketing and consumer behavior theories about the environment. The managerial implications of this study include the provision of significant findings for both domestic and international firms for the promotion of green products through focusing on consumer behavior towards the environment. This study provides important guidelines to boost positive attitudes in society towards green marketing and helps companies develop effective strategies to promote their green products.
\end{abstract}

Keywords: green marketing; consumer perceptions towards the environment; consumer beliefs towards the environment

\section{Introduction}

In the contemporary environment, green marketing has becoming increasingly significant globally. Green advertising is considered to be an effective method for the promotion of products, services, 
and business ideas, as it is deeply linked with the preservation of the natural environment [1]. For businesses operating under the current economic conditions, green product consumers are a major focus because they are considered to be a driving force for consumption. For the global economy, emerging trends involving green consumers have created a new market opportunity. Since the 1980s, green marketing and environmental marketing strategies have been a major interest for scholars. Green marketing and related ideas have been growing since the early 1990s [2,3]. Green marketing activities have been increasing at a significant rate and have obtained enough confidence from consumers to be sustainable and profitable since the 2010s. It has been observed that green marketing has experienced particularly rapid growth in the United States, and now constitutes a market worth USD 250 billion annually in the United States alone [3].

The idea of marketing management covers the retention of consumers in the long term through better marketing performance. However, in the contemporary business world, the concept of sustainability is covered under the title of green marketing in the existing literature. The idea of green marketing covered social dimensions in initial research, leading to a limited focus on environmental resources and the environmental impacts of conventional marketing in this context $[4,5]$. Green marketing has been well defined under the theoretical assumption of a resource-based view. This idea was initially proposed by [6] for the development of three capabilities. These capabilities include the protection of the environment from pollution, the development of sustainable products, and the ability to conduct product stewardship processes.

The aim of this study was to examine the impact of various green marketing approaches on consumer behaviors towards the environment in the United Arab Emirates (UAE). Numerous studies [7-11] have been conducted in both developed and developing economies. However, little attention has been paid towards the UAE from the perspective of green marketing and consumer behavior towards the environment. The UAE government plans to revamp its economy through climate change measures and by developing a green economy, but it requires the necessary data to facilitate such a transformation of its economy. In addition, the concepts of green marketing and consumer behavior towards the environment have not been examined in a collaborative way. In a general sense, in the field of marketing research, both green marketing and consumer behaviors have been studied separately [12-16]. With the passage of time, there has been an increase in consumer support for environmental protection, which has increased the demand for green products [15,17-23]. Therefore, we focused on filling this gap in the literature in the context of green marketing and consumer behaviors towards the environment. Based on our findings, this study provides an insight into ways to integrate these factors into the economy. This study attempts to answer the following questions:

1. Is there a significant relationship between eco-labeling (EL) and consumer behavior towards the environment?

2. Is there a significant relationship between green packaging and branding (GPB) and consumer behavior towards the environment?

3. Is there a significant relationship between green product, premium and pricing (GPPP) and consumer behavior towards the environment?

4. Is there a significant relationship between environmental concerns and beliefs (ECB) and consumer beliefs towards the environment (CBTE)?

\section{Literature Review}

In the existing body of literature, numerous studies have explained the significance of green marketing [24]. The concept of green marketing covers activities and trends including the modification of products, production processes, packaging and labeling, as well as advertising strategies [11,25]. From the perspective of [15] and [26], green marketing is the managing process which covers the identification, anticipation and satisfaction of the needs and wants of consumers. Such activities will be going on under the shadow of sustainable and profitable practices. It is the obligation of the business firm to accommodate the rapid changes in the environment due to increasing challenges while 
focusing on developing safer products [1,27]. For the sustainability of business firms, green marketing and related strategies are becoming a significant tool to achieve better business performance [28]. However, the concept of green marketing has evolved over time with the growth of environmental sustainability and the segmentation of the consumers [29]. Green marketing is the process of attempting to develop various strategies to target those consumers who have more concern for the environment [17]. Consequently, green consumers will be explained as the key consumer who will not consume products that may harm or damage living organisms [11].

However, the problem of sustainability is considered a key concern for both business organizations and individuals [3]. Since the 1990s, it has been observed that consumers have deep concern for the environment and have changed their behavior as a consequence [30]. Such behavior has provided a pathway for green marketing and sustainable products that are more environmentally friendly [31]. Empirical findings also indicated that marketers of green products have stated the gap between pro-environmental attitudes and green purchasing behavior [16,32]. The belief of individuals towards damage to the environment is entitled within the role of industry [33]. In another study [34], it was found that being environmentally friendly has an impact on all business categories. Meanwhile, other researchers [35] explained the concept that for purchase results, eco-labeling is an important factor that will influence the purchasing pattern of consumers. However, the confusion regarding green products in the mindset of the public has remained the key concern since the 1980s [36]. Meanwhile, those consumers who are ecologically conscious try to keep the environment cleaner in different ways. In a recent study [5,37], it was found that consumers have a lack of trust towards the plethora of eco-labeling on products. Other recent studies [38-40] indicated that green packaging and branding is a significant factor in guiding consumer behavior. Consumer behavior is, therefore, affected by green products and their pricing [39]. With the passage of time, communication about consumer beliefs regarding green items is increasing [19]. Therefore, it is necessary for information regarding green products to be communicated in a way that is accessible and understandable for various consumers [41]. To better understand the topic, we now address some of the key factors affecting this.

\section{Eco-Labeling}

Eco-labeling has a significant effect on the behavior of consumers towards products as it conveys information pertaining to the environmental concerns of consumers and characteristics of the product [42]. It addresses both business users and the range of consumers while providing them with product information related to the environment. Eco-labeling plays a major role in the development of environmental policy and in promoting behavior related to the use of environmentally friendly products and services. In addition, this fits within the multi-stakeholder policy and related frameworks [42].

However, the impression of eco-labeling has created some confusion for consumers and can create an ambiguous situation for them to predict the environmental quality of products [43]. The impact of a product on the environment is considered an integral part of its life cycle and it serves as a credible attribute. Eco-labels enable consumer to recognize those products and services which have the least environmental impact throughout their life [44]. This life goes from the extraction of raw materials to their production and then disposal. Various corporate policies and plans have been discussed in the existing literature regarding eco-labeling for both labeled and unlabeled products [44]. The competition of the products based on eco-labeling has also been examined [45]. In addition, the idea of eco-labeling is also covered under the title of green technology investment in the existing literature. For instance, studies have focused on investment, environmental quality behavior and competition in the price for eco-labeling [46]. It has been found that the quality of competition is tough for low-quality firms and their efficiency increases with the usage of eco-labeling as a key tool in reducing investment in low quality products [47]. To develop more sustainable and consumable products in the market, eco-labeling is a significant tool used by policy makers [48]. 


\section{Green Packaging and Branding (GPB)}

Green packaging and branding have not been a significant focus of research up until the last decade. Green branding is still yet to be explored by green marketers in today's economy. However, with growing environmental concerns, the awareness of the consumer regarding green packaging and branding has led to a more environmentally friendly attitude [49]. The attitude of consumers towards green products can be changed by the brands, as an efficient green position involves brand differentiation. It has also been stated that there is less commercial success for those products which do not reflect green attributes [50]. In addition, researchers have argued that for the success of green branding strategies, green positioning is an important element [51]. Numerous studies have addressed the significance and behavior of environmental products and their attributes [52]. From the perspective of European countries, consumers have exhibited positive attitudes towards eco-branded products [52].

\section{Green Products, Premium, and Pricing}

According to the findings of market research, the majority of customers in the marketplace are willing to pay higher prices for green products [53]. The idea of green pricing provides the customers with greater opportunity for investment in renewable energy. In numerous states, premium pricing strategies receive a significant response from customers. It has also been found that the quality of products with green premium pricing is higher [53]. Moreover, a proper and well-designed environmental regulation pricing strategy promotes green activities for improved competitive advantage in the market. Product manufacturing and pricing strategies have a direct impact on the profitability of a business; hence, adopting the appropriate pricing strategy with environmental consideration in mind can promote a business [54]. Various factors play a role in defining the green pricing of products. Green pricing and related programs have a significant influence on consumer participation rates [55].

\section{Environmental Concerns and Beliefs (ECB)}

Environmental concerns and problems are linked with all business enterprises and citizens around the globe [3]. It has been found that consumers are very much concerned about the environment and have changed their behavior gradually in favor of its protection [56]. Due to this emerging issue, a new market for green products has emerged and active consumers have made it more significant. The reason for this is that the active role of consumers is considered a means through which to promote the protection of the environment $[5,31,57]$. Among several behaviors, to create a value for the environment is important [58]. However, it has also been expressed that those consumers who are more conscious towards the environment do not necessarily behave in an ecologically friendly way [10]. Empirical findings have explained that the intention to recycle products, care about environmental pollution and pay for more ecological products have been reflected in very few customers [59]. To address the objectives of this study, the following hypotheses were developed to assess the relationship between green marketing approaches and consumer behavior towards the environment.

H1. There is a significant relationship between eco-labeling (EL) and consumer behavior towards the environment;

H2. There is a significant relationship between the green packaging and branding (GPB) and consumer behavior towards the environment;

H3. There is a significant relationship between the green product, premium and pricing (GPPP) and consumer behavior towards the environment;

H4. There is a significant relationship between the environmental concerns and beliefs (ECB) and consumer beliefs towards the environment (CBTE). 


\section{Research Methodology}

To achieve the objectives of this study, a questionnaire was developed with several sections (see Appendix A). The green marketing factors we included were eco-labeling (EL), green packaging and branding (GPB), and green product, premium and pricing (GPPP). The fourth factor was environmental concerns and beliefs (ECB). The final factor for the study, consumer beliefs towards the environment (CBTE), was added to the questionnaire with latent indicators. All of the items in the questionnaire were measured on a five-point Likert scale ( 1 , strongly disagree, to 5 , strongly agree). Various statistical techniques were applied to analyze the data using SPSS-AMOS version 21.

In addition, confirmatory factor analysis (CFA) was conducted to check the validity and reliability of the construct. Before the final consideration of the questionnaire, pilot testing was carried out using 25 randomly selected consumers with a minor modification in the wording of questions. The target population of the study consisted of various individuals from different age groups, ethnic backgrounds, and social status classes in UAE. This provided data regarding the behavior of consumers based on their choices, attitudes, social status, financial preferences and purchasing decisions. To target the desired consumers, various markets were visited and opinions from consumers were collected using the developed questionnaire. Finally, a sample of 359 respondents was obtained with no missing responses. Data were collected over a period of 6.5 weeks.

\section{Empirical Findings}

For the analysis, both factor analysis and structural equation modeling were used. Confirmatory factor analysis (CFA) is considered a suitable technique to describe whether the listed items explain the exact construct or not. Figure 1 shows the structure of the confirmatory factor analysis for the present study. Four major constructs-eco-labeling (EL), green packaging and branding (GPB), green products, premium, and pricing (GPPP) and environmental concerns and beliefs (ECB) - were considered from a previous study [27]. The value for the goodness of fit was measured using chi-square tests, root mean square error approximation (RMSEA) goodness of fit index (GFI), adjusted goodness of fit index (AGFI), comparative fit index (CFI) and Tucker Lewis index (TLI), as they are accepted methods for our analysis, as explained in the literature [60,61]. We calculated the goodness of fit indices and the value of composite reliability is presented in Table 1. For all constructs, the value of CR is $>0.70$ and explains the convergent validity for the model. Additionally, Table 2 presents the value of the symmetric matrix between the sample covariance and implied covariance of the model. For the goodness-of-fit analysis, a small difference is suggested such as in [62].

After deleting items which had a factor loading of $<0.50$, Figure 2 shows the appropriate loadings for the remaining items. The values of the factor loadings for the CBTE are also presented.

After the consideration of the CFA, a structural equation model was developed, considering the green packaging and branding (GPB), green products, premium, and pricing (GPPP) and environmental concerns and beliefs (ECB) factors as latent variables. Figure 3 provides the structure model of the study. Findings for each construct with the consumer belief towards the environment (CBTE) are explained below.

Table 1. Fitted values for CFA.

\begin{tabular}{ccc}
\hline Indices & Result & Decision \\
\hline Chi-square & 344.798 & Accepted \\
Root mean squared error approximation (RMSEA) & 0.054 & Accepted \\
GFI & 0.907 & Accepted \\
Adjusted goodness of fit index (AGFI) & 0.881 & Accepted \\
Comparative fit index (CFI) & 0.904 & Accepted \\
Tucker Lewis index (TLI) & 0.899 & Accepted \\
\hline
\end{tabular}



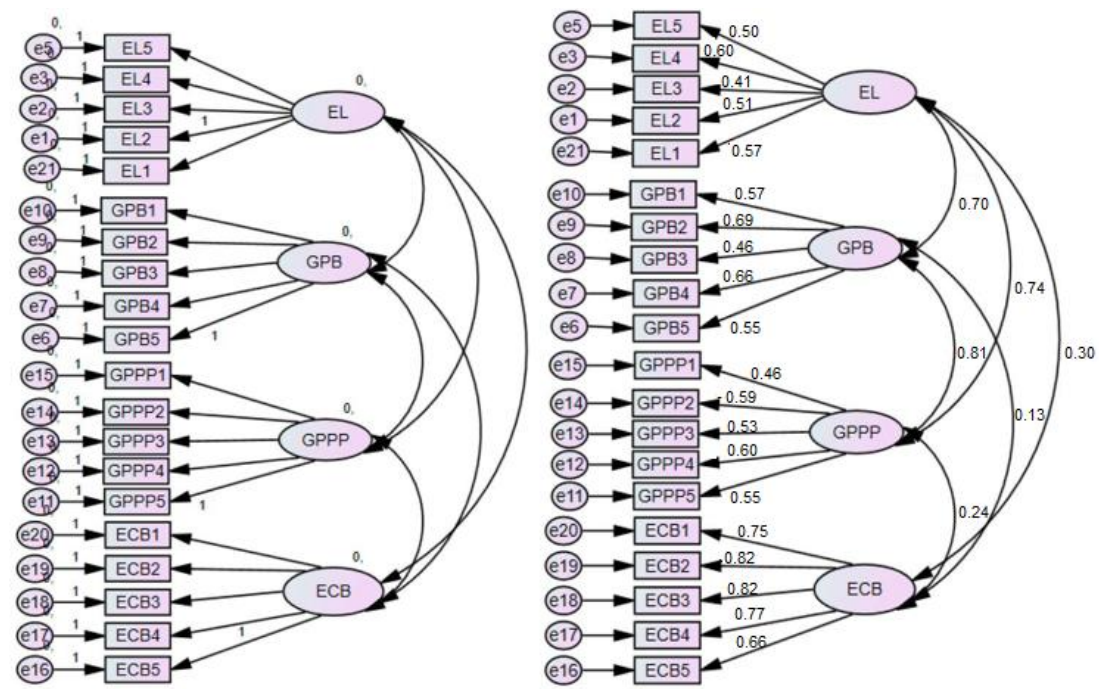

Figure 1. Measurement model of the study: confirmatory factor analysis (CFA), with the input and output path diagram. Note: Eco-Labeling (EL), Green Packaging and Branding (GPB), Green Products, Premium, and Pricing GPPP.

Table 2. Regression weights for Group 1—default model.

\begin{tabular}{|c|c|c|c|c|c|c|}
\hline Variables and Items & Directions & Variables and Items & Estimate & SE & CR & $\mathbf{P}$ \\
\hline CBTE & $<-$ & EL & 0.40 & 0.16 & 2.39 & $0.017 * *$ \\
\hline CBTE & $<-$ & GPPP & 0.41 & 0.08 & 5.02 & $* * *$ \\
\hline CBTE & $<-$ & ECB & 0.64 & 0.09 & 7.12 & $* * *$ \\
\hline CBTE & $<-$ & GPB & -0.24 & 0.16 & -1.50 & 0.132 \\
\hline EL2 & $<-$ & EL & 1.00 & & & \\
\hline EL3 & $<-$ & EL & 0.88 & 0.15 & 5.67 & $* * *$ \\
\hline EL4 & $<-$ & EL & 1.26 & 0.17 & 7.05 & $* * *$ \\
\hline EL5 & $<-$ & EL & 1.04 & 0.16 & 6.21 & $* * *$ \\
\hline GPB5 & $<-$ & GPB & 1.00 & & & \\
\hline GPB4 & $<-$ & GPB & 1.15 & 0.14 & 8.18 & $* * *$ \\
\hline GPB3 & $<-$ & GPB & 0.75 & 0.11 & 6.46 & $* * *$ \\
\hline GPB2 & $<-$ & GPB & 1.11 & 0.13 & 8.38 & $* * *$ \\
\hline GPB1 & $<-$ & GPB & 0.97 & 0.13 & 7.47 & $* * *$ \\
\hline GPPP5 & $<-$ & GPPP & 1.00 & & & \\
\hline GPPP4 & $<-$ & GPPP & 1.06 & 0.14 & 7.57 & $* * *$ \\
\hline GPPP3 & $<-$ & GPPP & 0.96 & 0.13 & 6.98 & $* * *$ \\
\hline GPPP2 & $<-$ & GPPP & 1.01 & 0.13 & 7.43 & $* * *$ \\
\hline GPPP1 & $<-$ & GPPP & 0.84 & 0.13 & 6.30 & $* * *$ \\
\hline ECB5 & $<-$ & ECB & 1.00 & & & \\
\hline ECB4 & $<-$ & ECB & 1.12 & 0.09 & 11.93 & $* * *$ \\
\hline ECB3 & $<-$ & ECB & 1.32 & 0.10 & 12.57 & $* * *$ \\
\hline ECB2 & $<-$ & ECB & 1.24 & 0.09 & 12.65 & $* * *$ \\
\hline ECB1 & $<-$ & ECB & 1.15 & 0.09 & 11.68 & $* * *$ \\
\hline EL1 & $<-$ & EL & 1.12 & 0.16 & 6.82 & $* * *$ \\
\hline CBTE2 & $<-$ & CBTE & 1.10 & 0.13 & 8.37 & $* * *$ \\
\hline CBTE5 & $<-$ & CBTE & 0.25 & 0.09 & 2.69 & $0.007^{* *}$ \\
\hline CBTE3 & $<-$ & CBTE & 1.08 & 0.13 & 8.10 & $* * *$ \\
\hline CBTE4 & $<-$ & CBTE & 0.53 & 0.09 & 5.88 & $* * *$ \\
\hline
\end{tabular}




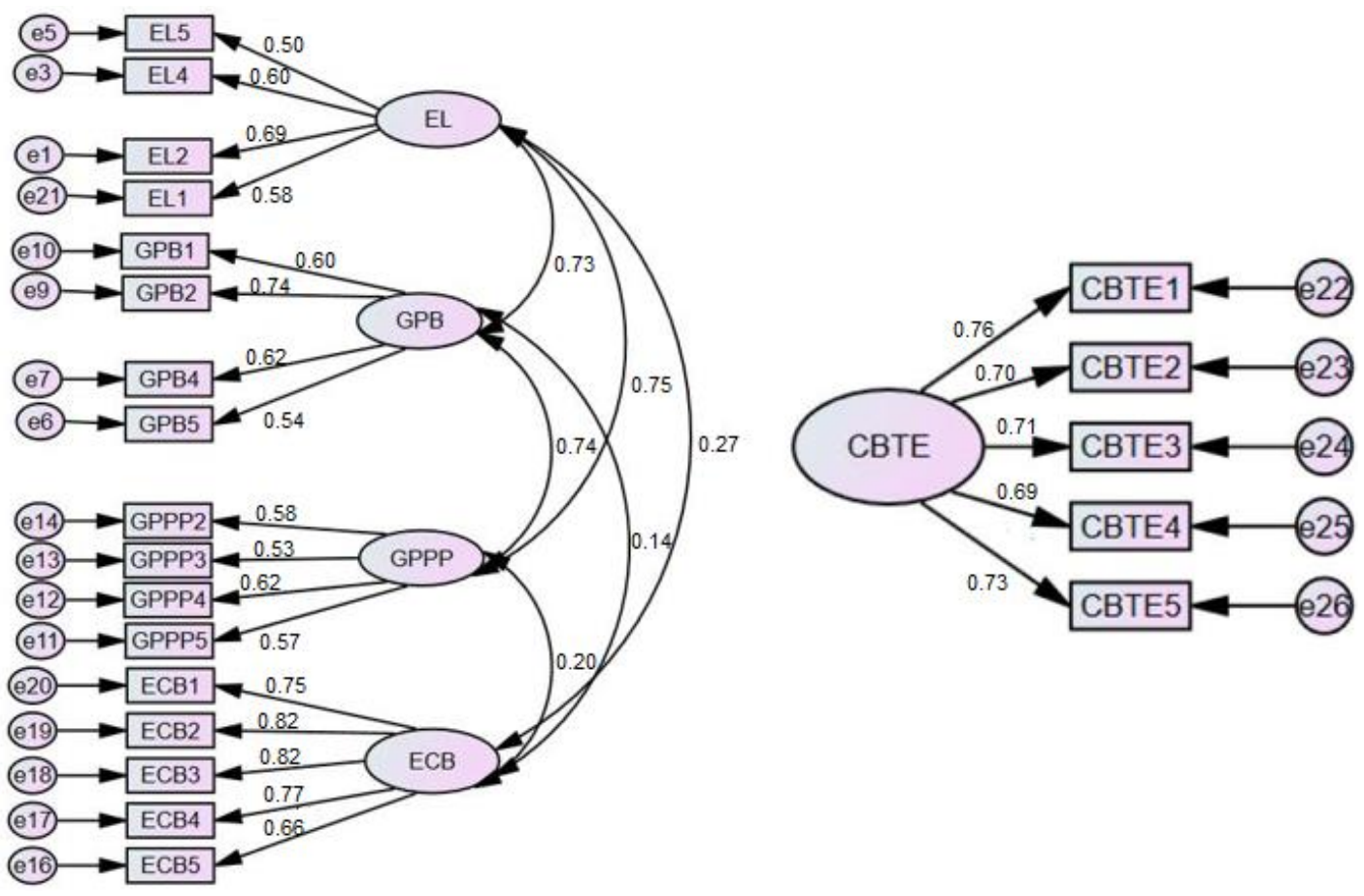

Figure 2. Values of the factor loadings for the Consumer Beliefs towards the Environment CBTE.

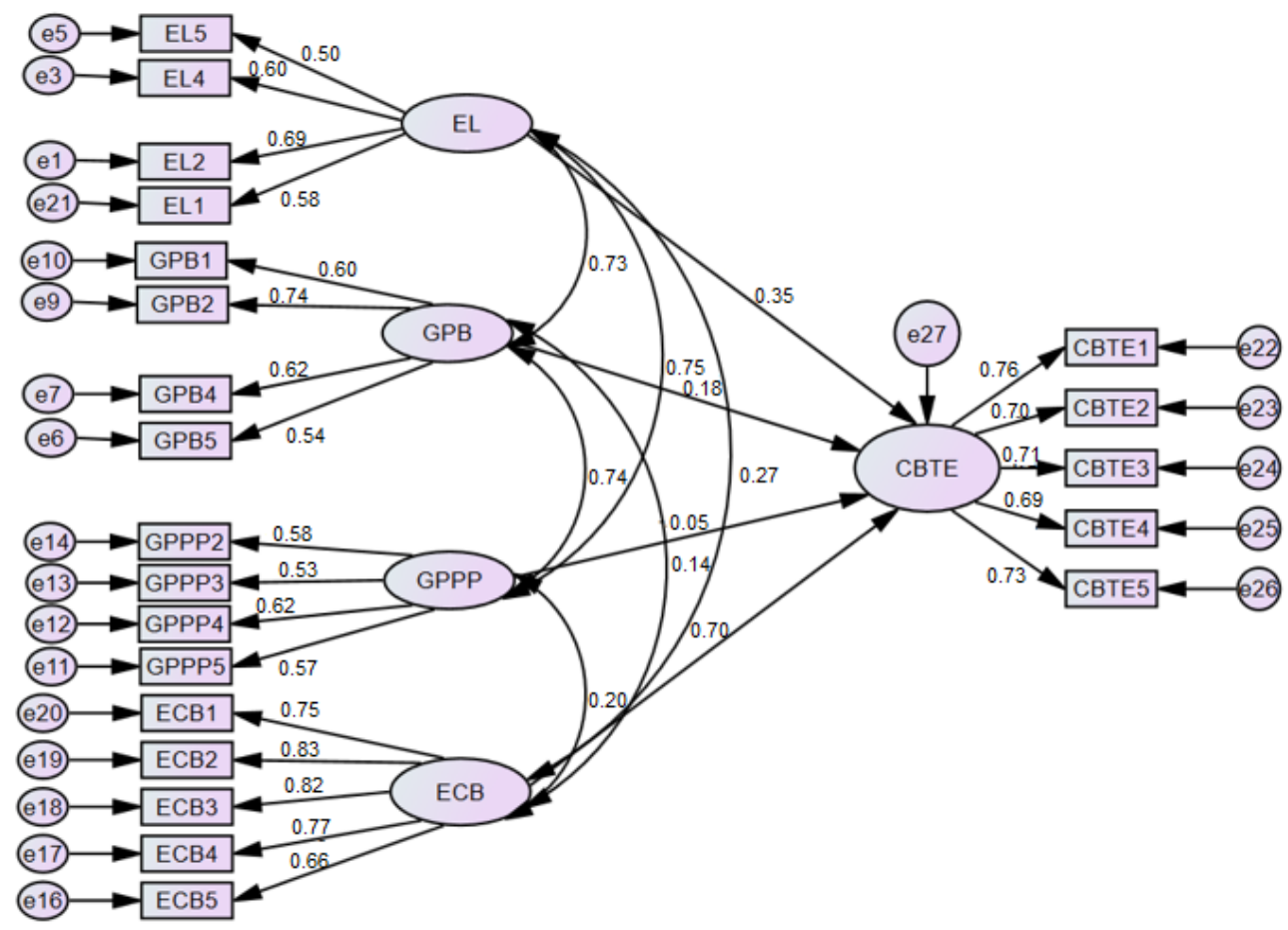

Figure 3. Structural equation model used in this study.

\section{Eco-Labeling (EL) and Consumer Belief towards Environment (CBTE)}

The eco-labeling (EL) factor, with the help of considered items, had a high loading in the CFA. The coefficients from EL to EL2, EL to EL3, EL to EL4 and EL to EL5 explained the significant variation in the data, statistically different from zero. The same case was observed from GPB to GBP1, GBP2, GBP3, and GBP4, which explained the significant regression estimates. The third latent construct, GPPP, also explained a significant regression weight regarding GPP1, GPPP2, GPPP3, and GPPP4. In the case of ECB (ECB1, ECB2, ECB3, ECB4), all of the regression coefficients demonstrated significant 
regression weights. In addition, CBTE (main outcome factor of the study) also explained significant regression weights for CBTE2, CBTE3, CBTE4 and CBTE5. The combined effect of the four predictors is also presented in Table 2. It can be seen that the impact of EL on CBTE is 0.35, indicating a positive and significant impact. This implies that eco-labeling positively influences consumer beliefs towards the environment in the UAE. The combined effect can also be interpreted in a sense that eco-labeling is attractive for green products, as it means there is sufficient information on the label, it is easy to read, is linked to one's life style and provides an accurate level of information. All of these factors had a positive and significant impact on CBTE. The trend of such positive and significant findings has provided enough evidence to accept the first hypothesis regarding the combined effect of eco-labeling with the selected indicators. In addition, survey findings for the second latent construct, GPB, exhibited a negative but insignificant impact on CBTE. This impact implies that there is a negative but insignificant impact of various items for GPB under the title of important information on green packaging, the re-use of packaging and feeling good about buying green products. Based on this negative and insignificant impact, the second research hypothesis cannot be accepted. The third latent construct, GPPP, exhibited a significant and positive impact on CBTE. The value of the coefficient was 0.412 , indicating a combined effect of GPPP on CBTE. This combined effect implies that consumers trust that a portion of the price for green products goes toward a significant environmental cause, highlights the importance of green products in the UAE, shows that there is an intention to pay higher prices for green products, that the eco-image of green products is important, and that there should be more visibility for the marketing of green products. The value of Composite Reliability CR is 5.02, which indicates a standard error of 5.02 above zero for the coefficient of GPPP. Based on the significant value of the coefficient, the fourth research hypothesis can be accepted. The fourth latent construct for this study was the environmental concerns and beliefs of the consumers (ECB), which contained five items. The value of the regression coefficient for ECB exhibited a significant and positive influence on CBTE. It showed a 0.70 positive impact on CBTE, with a significant $p$-value and $\mathrm{CR}$ of 7.12. The combined effect of ECB covers items including beliefs surrounding the Earth being able to support limited individuals, that the planet has a delicate and easily upset natural balance, the disastrous consequences in nature due to human interference, the abuse of the environment by mankind, and the adaptation of natural environment.

\section{Conclusions and Future Directions}

In terms of green marketing, there is rapid ongoing change for companies regarding the re-structuring of their products and their impact on the environment. In both research and business practices, green marketing is observed as an ongoing phenomenon, as it is based on the sustainability of the environment. This study was carried out in the UAE to observe the impact of green marketing approaches and consumer beliefs and the behavior of consumers towards the environment. Based on our empirical findings, we argue that various green marketing approaches have a positive and significant influence on consumer behavior towards the environment. In addition, we also highlighted the importance of green marketing for businesses. We propose that companies should consider the findings for the development of eco-friendly strategies and their impact on value creation in the contemporary business environment. The study findings also provide a meaningful path forwards for policy makers responsible for the creation and development of marketing strategies. Previous research indicated several gaps in the literature of green marketing approaches and their impact on the behavior of consumers. Most studies in this area were focused on the relationship between one or two factors of green marketing and consumer behavior [63-65]. Additionally, findings generally lacked empirical evidences. Here, we attempted to empirically assess the impact and significance of green marketing approaches on consumer behavior towards the environment. Furthermore, we incorporated four important factors in determining consumer behavior towards the environment. 


\section{Key Limitations and Future Research}

We analyzed the impact of green marketing approaches and consumer beliefs towards the environment. However, we identified the following core limitations:

1. We focused on a limited number of consumers who belong to only one region of the UAE.

2. We did not provide any evidence regarding the consideration of businesses dealing with green marketing and related product lines.

3. Our findings need to be further validated with a broader analysis for the effectiveness of green marketing and related approaches.

4. Due to the lack of a definition for green marketing and related patterns, the present study has covered some pre-limited indicators for green marketing.

To enhance our future understanding, there is a need for future research that considers the above limitations, specifically for consumer behavior related to environment. Future research can also be expanded while considering the concept of environmental sustainability and should include some qualitative techniques to evaluate green marketing and its effect, specifically in terms of business performance. In addition, the research context can be extended towards businesses and similar industries for better strategic comparisons regarding green marketing and consumer perceptions towards the environment. In addition, some studies focusing on supplementary qualitative approaches with focus group discussions could be conducted in the future.

Author Contributions: Conceptualization of the research, methodology design, software handling, validation of results, formal analysis, writing of original draft, and revision of paper were mainly done by M.S.S. Investigation, resource handling, visualization of data, and supervision was done by N.H.A.-K. with the help of M.A.B.A.S. on resource handling and investigation. Project administration, validation, and data collection were mainly done by A.M. with the assistance of M.A. on data collection process. All authors have read and agreed to the published version of the manuscript.

Funding: This research received no external funding.

Conflicts of Interest: The authors declare no conflict of interest.

\section{Abbreviations}

CBTE Consumer Beliefs towards the Environment

CFA Confirmatory Factor Analysis

ECB Environmental Concerns and Beliefs

EL Eco-Labeling

GPB Green Packaging and Branding

GPPP Green Products, Premium, and Pricing

\section{Appendix A}

Table A1. List of Items in the Questionnaire.

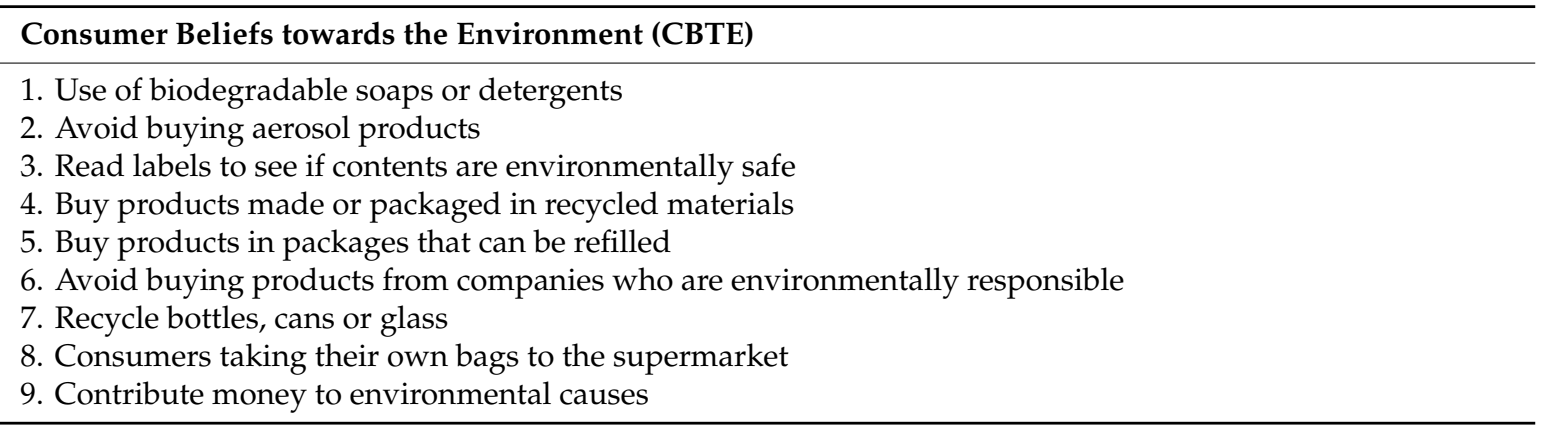


Table A1. Cont.

\section{Environmental Concerns and Beliefs (ECB)}

1. The Earth is approaching the limit of the number of people it can support

2. The balance of nature is very delicate and easily upset

3. Humans have the right to modify the natural environment to suit their needs

4. Human interference with nature often has disastrous consequences

5. Plants and animals exist primarily to be used by humans

6. Humans have to control industrial growth to maintain a healthy economy

7. Humans must live in harmony with nature in order to survive

8. Humans need to adapt to the natural environment because they can remake it to suit their own needs

9. There are limits to which the industrialized society can expand

10. Mankind is severely abusing the environment

\section{Eco-Labeling (EL)}

1. Eco-labels are eye catching on green products

2. Sufficient information is provided on eco-labels

3. I believe that eco-labels are easy to read

4. Green products are marketed to me in a way which I really find engaging and relevant to my lifestyle

5. Information on eco-labels is accurate for green products

6. It is easy for me to identify green products in UAE

\section{Green Packaging and Branding (GPB)}

1. I acknowledge that the information on packaging is an important criterion

2. It is important to reuse or recycle packaging after use

3. Biodegradable packaging is an important consideration for green customers

4. I feel good about buying brands which are less damaging to the environment

5. I trust well known green branded products in UAE

Green Products, Premium, and Pricing (GPPP)

1. I accept as true that a portion of the price for green products goes to a worthy environmental cause

2. I consider that green products are very important in the context of UAE

3. I think that it is reasonable to pay a higher price for products that are produced in an ecological way

\section{References}

1. Hasan, Z.; Ali, N.A. The impact of green marketing strategy on the firms performance in Malaysia. Proc. Soc. Behav. Sci. 2015, 172, 463-470. [CrossRef]

2. Chan, R.Y.; Lau, L.B. Antecedents of green purchases: A survey in China. J. Consum. Mark. 2000, 17, 338-357. [CrossRef]

3. Papadopoulos, I.; Karagouni, G.; Trigkas, M.; Platogianni, E. Green marketing: The case of Greece in certified and sustainably managed timber products. EuroMed J. Bus. 2010, 5, 166-190. [CrossRef]

4. Kumar, P. State of green marketing research over 25 years (1990-2014) Literature survey and classification. Mark. Intell. Plan. 2016, 34, 137-158. [CrossRef]

5. Kardos, M.; Gabor, M.R.; Cristache, N. Green marketing's roles in sustainability and ecopreneurship. Case study: Green packaging's impact on Romanian young consumers' environmental responsibility. Sustainability 2019, 11, 873. [CrossRef]

6. Hart, O. Firms, Contracts, and Financial Structure; Clarendon Press: Oxford, UK, 1995.

7. Cherian, J.; Jacob, J. Green marketing: A study of consumers' attitude towards environment friendly products. Asian Soc. Sci. 2012, 8, 117. [CrossRef]

8. Laroche, M.; Bergeron, J.; Barbaro-Forleo, G. Targeting consumers who are willing to pay more for environmentally friendly products. J. Consum. Mark. 2001, 18, 503-520. [CrossRef]

9. Mostafa, M.M. Gender differences in Egyptian consumers' green purchase behaviour: The effects of environmental knowledge, concern and attitude. Int. J. Consum. Stud. 2007, 31, 220-229. [CrossRef]

10. Pickett-Baker, J.; Ozaki, R. Pro-environmental products: Marketing influence on consumer purchase decision. J. Consum. Mark. 2008, 25, 281-293. [CrossRef]

11. Podvorica, G.; Ukaj, F. The role of consumers' behaviour in applying green marketing: An economic analysis of the non-alcoholic beverages industry in kosova. Wroclaw Rev. Law Adm. Econ. 2020, 9, 1-25. [CrossRef] 
12. Bamossy, G.J.; Solomon, M.R. Consumer Behaviour: A European Perspective; Pearson Education: London, UK, 2016.

13. Horner, S.; Swarbrooke, J. Consumer Behaviour in Tourism; Routledge: London, UK, 2016.

14. Kumar, P. Green marketing innovations in small Indian firms. World J. Entrep. Manag. Sustain. Dev. 2015, 11, 176-190. [CrossRef]

15. Peattie, K. Environmental Marketing Management: Meeting the Green Challenge; Financial Times Management: Upper Sadle River, NJ, USA, 1995.

16. Farzin, A.; Yousefi, S.; Amieheidari, S.; Noruzi, A. Effect of green marketing instruments and behavior processes of consumers on purchase and use of e-books. Webology 2020, 17, 202-215. [CrossRef]

17. Polonsky, M.J. An introduction to green marketing. In Global Environment: Problems and Policies; Atlantic Publishers: New Delhi, India, 2008.

18. Martin, B.; Simintiras, A.C. The impact of green product lines on the environment. Mark. Intell. Plan. 1995, 13, 16-23. [CrossRef]

19. Ottman, J. The New Rules of Green Marketing: Strategies, Tools, and Inspiration for Sustainable Branding; Routledge: London, UK, 2017.

20. Ottman, J.; Books, N.B. Green marketing: Opportunity for innovation. J. Sustain. Prod. Des. 1998, 60, $136-667$.

21. Rasool, Y.; Iftikhar, B.; Nazir, M.N.; Kamran, H.W. Supply chain evolution and green supply chain perspective. Int. J. Econ. Commer. Manag. 2016, 4, 716-724.

22. Salzman, J. Informing the green consumer: The debate over the use and abuse of environmental labels. J. Ind. Ecol. 1997, 1, 11-21. [CrossRef]

23. Vandermerwe, S.; Oliff, M.D. Customers drive corporations. Long Range Plan. 1990, 23, 10-16. [CrossRef]

24. Abraham, N. The apparel aftermarket in India-A case study focusing on reverse logistics. J. Fash. Mark. Manag. Int. J. 2011, 15, 211-227. [CrossRef]

25. Polonsky, M.J. Green marketing regulation in the US and Australia: The Australian checklist. Greener Manag. Int. 1994, 5, 44-53.

26. Welford, R. Hijacking Environmentalism: Corporate Responses to Sustainable Development; Routledge: London, UK, 2013.

27. Juwaheer, T.D.; Pudaruth, S.; Noyaux, M.M.E. Analysing the impact of green marketing strategies on consumer purchasing patterns in Mauritius. World J. Entrep. Manag. Sustain. Dev. 2012, 8, 36-59. [CrossRef]

28. Papadas, K.-K.; Avlonitis, G.J.; Carrigan, M. Green marketing orientation: Conceptualization, scale development and validation. J. Bus. Res. 2017, 80, 236-246. [CrossRef]

29. Dangelico, R.M.; Vocalelli, D. "Green Marketing": An analysis of definitions, strategy steps, and tools through a systematic review of the literature. J. Clean. Prod. 2017, 165, 1263-1279. [CrossRef]

30. Simon, F.L. Marketing green products in the triad. Columbia J. World Bus. 1992, 27, $268-285$.

31. Cleveland, M.; Kalamas, M.; Laroche, M. Shades of green: Linking environmental locus of control and pro-environmental behaviors. J. Consum. Mark. 2005, 22, 198-212. [CrossRef]

32. Ferraz, S.B.; Romero, C.B.A.; Laroche, M.; Veloso, A.R. Green products: A cross-cultural study of attitude, intention and purchase behavior. RAM Rev. Adm. Mackenzie 2017, 18, 12-38. [CrossRef]

33. Barber, N. "Green" wine packaging: Targeting environmental consumers. Int. J. Wine Bus. Res. 2010, 22, 423-444. [CrossRef]

34. Prahalad, C.K.; Hamel, G. Strategy as a field of study: Why search for a new paradigm? Strateg. Manag. J. 1994, 15, 5-16. [CrossRef]

35. Gallastegui, I.G. The use of eco-labels: A review of the literature. Eur. Environ. 2002, 12, 316-331. [CrossRef]

36. D'Souza, C.; Taghian, M.; Lamb, P. An empirical study on the influence of environmental labels on consumers. Corp. Commun. Int. J. 2006, 11, 162-173. [CrossRef]

37. Bhaskaran, S. Incremental innovation and business performance: Small and medium-size food enterprises in a concentrated industry environment. J. Small Bus. Manag. 2006, 44, 64-80. [CrossRef]

38. Chen, Y.-S.; Hung, S.-T.; Wang, T.-Y.; Huang, A.-F.; Liao, Y.-W. The influence of excessive product packaging on green brand attachment: The mediation roles of green brand attitude and green brand image. Sustainability 2017, 9, 654. [CrossRef]

39. Mishra, P.; Jain, T.; Motiani, M. Have green, pay More: An empirical investigation of consumer's attitude towards green packaging in an emerging economy. In India Studies in Business and Economics; Springer: Singapore, 2017; pp. 125-150. [CrossRef] 
40. Yang, Y.-C.; Zhao, X. Exploring the relationship of green packaging design with consumers' green trust, and green brand attachment. Soc. Behav. Pers. Int. J. 2019, 47, 1-10. [CrossRef]

41. Mazur, A. How did the fracking controversy emerge in the period 2010-2012? Public Underst. Sci. 2014, 25, 207-222. [CrossRef] [PubMed]

42. Brécard, D. Consumer misperception of eco-labels, green market structure and welfare. J. Regul. Econ. 2017, 51, 340-364. [CrossRef]

43. Harbaugh, R.; Maxwell, J.W.; Roussillon, B. Label confusion: The Groucho effect of uncertain standards. Manag. Sci. 2011, 57, 1512-1527. [CrossRef]

44. Bonroy, O.; Constantatos, C. On the economics of labels: How their introduction affects the functioning of markets and the welfare of all participants. Am. J. Agric. Econ. 2014, 97, 239-259. [CrossRef]

45. Fischer, C.; Lyon, T.P. Competing environmental labels. J. Econ. Manag. Strat. 2014, 23, 692-716. [CrossRef]

46. Rochikashvili, M.; Bongaerts, J. How eco-labelling influences environmentally conscious consumption of construction products. Sustainability 2018, 10, 351. [CrossRef]

47. Amacher, G.S.; Koskela, E.; Ollikainen, M. Environmental quality competition and eco-labeling. J. Environ. Econ. Manag. 2004, 47, 284-306. [CrossRef]

48. Horne, R. Limits to labels: The role of eco-labels in the assessment of product sustainability and routes to sustainable consumption. Int. J. Consum. Stud. 2009, 33, 175-182. [CrossRef]

49. Swenson, M.R.; Wells, W.D. Useful Correlates of Pro-Environmental Behavior. In Social Marketing: Theoretical and Practical Perspectives; Goldberg, M.E., Fishbein, M., Middlestadt, S.E., Eds.; Psychology Press: Hove, UK, 2018; pp. 91-109.

50. Hartmann, P.; Ibáñez, V.A.; Sainz, F.J.F. Green branding effects on attitude: Functional versus emotional positioning strategies. Mark. Intell. Plan. 2005, 23, 9-29. [CrossRef]

51. Meffert, H.; Kirchgeorg, M. Das neue leitbild sustainable development: Der weg ist das ziel. Harv. Bus. Manag. 1993, 15, 34-45.

52. Wüstenhagen, R.; Bilharz, M. Green energy market development in Germany: Effective public policy and emerging customer demand. Energy Policy 2006, 34, 1681-1696. [CrossRef]

53. Swezey, B.G.; Bird, L. Utility Green Pricing Programs: What Defines Success? National Renewable Energy Laboratory: Golden, CO, USA, 2001.

54. Chen, Y.J.; Sheu, J.-B. Environmental-regulation pricing strategies for green supply chain management. Transp. Res. Part E Logist. Transp. Rev. 2009, 45, 667-677. [CrossRef]

55. Bae, J.H.; Rishi, M. Increasing consumer participation rates for green pricing programs: A choice experiment for South Korea. Energy Econ. 2018, 74, 490-502. [CrossRef]

56. Arbuthnot, J. The roles of attitudinal and personality variables in the prediction of environmental behavior and knowledge. Environ. Behav. 1977, 9, 217-232. [CrossRef]

57. Cleveland, M.; Bartikowski, B. Cultural and identity antecedents of market mavenism: Comparing Chinese at home and abroad. J. Bus. Res. 2018, 82, 354-363. [CrossRef]

58. Hoyer, W.; MacInnis, D. Consumer Behavior, 3rd ed.; CENGAGE: Boston, MA, USA, 2004.

59. Sloan, A. Top 10 Functional Food Trends. Food Technol. 2004, 58, $28-51$.

60. Hooper, D.; Coughlan, J.; Mullen, M.R. Structural equation modelling: Guidelines for determining model fit. Electron. J. Bus. Res. Methods 2008, 6, 53-60.

61. Steiger, J.H. Understanding the limitations of global fit assessment in structural equation modeling. Personal. Individ. Differ. 2007, 42, 893-898. [CrossRef]

62. Bentler, P.M.; Bonett, D.G. Significance tests and goodness of fit in the analysis of covariance structures. Psychol. Bull. 1980, 88, 588. [CrossRef]

63. Alansaari, A.; El Sergany, M. Assessment of Public Purchase Behavior Towards Household Green Products in United Arab Emirates (UAE). In Proceedings of the 16th International Conference on Environmental Science and Technology, Rhodes, Greece, 4-7 September 2019.

64. Alomari, B.M.A.; Alomari, I.A.A. Green marketing and its impact on consumer purchasing behavior and the tourism sector/an analytical study-The Jordanian green market. J. Econ. Bus. Market Res. 2020, 1, 8-24. 
65. Dubey, A.R. Study of factors of green loyalty in context of green products and services: Mediation evidences of green trust of customers of hotel chains in UAE. J. Asian Bus. Manag. 2018, 10, 87-100.

Publisher's Note: MDPI stays neutral with regard to jurisdictional claims in published maps and institutional affiliations.

(C) 2020 by the authors. Licensee MDPI, Basel, Switzerland. This article is an open access article distributed under the terms and conditions of the Creative Commons Attribution (CC BY) license (http://creativecommons.org/licenses/by/4.0/). 